\title{
The Brandt Commission Report*
}

\section{Memorandum prepared by the Foreign and Commonwealth Office for the Overseas Development Sub-committee of the Foreign Affairs Committee}

\section{Analysis and General Approach}

1. The Government have already made clear their appreciation of the Commission's work. The Commission has focussed public attention on a wide range of fundamental problems facing the world over the next decade and beyond. They have had an important impact on opinion in Britain. The Government hope that they will make an equal impression in other countries.

2. The Government share the Commission's deep concern about the outlook for the world economy and for the developing countries in particular. The later 1970 s were difficult years for most developing countries. They were badly affected by rising oil prices, which sharply reduced the prospects for growth in the world economy, as well as aggravating existing inflation. Further increases in oil prices and persistent inflation mean that the prospects for the 1980s and beyond are yet more sombre. The situation has worsened even since the Report was published.

3. The Government also share the Commission's view that solutions must be sought on the basis of mutual interest, though they may differ on where mutual interest may best be found. The Government agree with the Report's judgement |page 65|: 'The North-South Dialogue has suffered from the atmosphere which prevailed in the past of Southern 'demands' and Northern 'concessions'; it is only in more recent years that prominent leaders of opinion have begun to call for the Dialogue to be regarded as an opportunity for partnership, one in which all sides can work for their mutual benefit'.

4. The Government do not believe that there is a single sharp division between North and South. The world contains a very wide variety of countries at differing stages of development. The mutual interest of all countries, whether industrialised or developing, can best be served by means of a single world economic system which can accommodate them all. The Government believe strongly in the merits of the present world economic system, with its wide reliance on open markets for trade and financial flows. The system has regularly and flexibly adapted to changing

*note: Crown Copyright. reproduced with the permission of the Controller of Her Majesty's Stationery Office. conditions and can be adapted further. This gives the best hope of overcoming present difficulties and providing a firm basis for future growth.

5. The present system offers an opportunity to all those engaged in economic activity to contribute towards soundly-based development. In particular:

a) Progressively expanding international trade can make a powerful contribution. Those developing countries which have achieved the greatest advance towards prosperity have done so through a rapid growth of trade-some even in the adverse conditions of the 1970s. Flows of trade in both directions between developed and developing countries are 35 times greater than official flows of aid. Britain takes 18 per cent of its imports from developing countries, including OPEC, (worth $£ 8700 \mathrm{mn}$ in 1979) and sends 22 per cent of its exports to them $(£ 9300 \mathrm{mn})$. Comparable figures for the European Community as a whole are 26 per cent and 23 per cent. The Community absorbs 25 per cent of the total exports of non-oil developing countries. Faster growth of world trade depends on giving all encouragement to traders, keeping restrictions and controls to a minimum. The Government are therefore firmly resolved to continue to resist protectionist pressures to the greatest extent possible, despite the growing difficulties of the world economy, and have endorsed the OECD Declaration on Trade issued on 4 June 1980 .

b) Increased trade between developed and developing countries implies changes in industrial structure in developed countries, as advocated by the Report, eg in chapter 11. Successive British Governments have recognised the need for structural change in response to market forces and the mutual benefit that can flow from it. During the 1970 s 10 per cent of Britain's imports of manufactures came from 'newly industrialising countries', while these countries also remain important markets for our own exports of manufactures. These imports have risen as rapidly as imports from other sources, and very fast in certain sectors. The necessary structural changes involve social costs, especially in times of slow growth. The Government recognise that special arrangements may be necessary in a few particularly sensitive sectors such as textiles, to mitigate the disturbances caused.

Bulletin. 1981, vol 12 no 2. Institute of Development Studies. Sussex 
c) Private direct investment from the developed countries can greatly contribute to the advancement of the developing countries. The Government welcome the recognition given to this in the Report, especially in chapter 12. Private capital helped development long before Government aid became common. The Government have taken a number of measures to promote private investment overseas. They have removed all exchange controls on outward capital movements; offered investment insurance against political risks; and concluded bilateral investment promotion and protection agreements. They support the new arrangements agreed in the Lomé Convention, particularly those to support mining investment where recent trends have been disquieting. But they look to developing countries themselves to provide a climate of confidence for external investors and stable conditions in which they can operate.

6. Alongside the private sector, governments have their own role to play. This involves:

a) responsible national economic policies;

b) international cooperation to maintain and adapt the rules governing the world economic system and to help other governments in difficulty.

\section{As regards national policies:}

a) The Report, especially in chapters 1 and 3, stresses the importance, for the future of developing countries, of restoring growth to the world economy. The Western industrial countries, including the United Kingdom, must be the main motors of this growth. The record of the 1970 s shows that durable growth can only be achieved if these countries adjust to the higher cost of oil and bring inflation under control. This must be the first priority of the industrialised countries, as was confirmed at the Venice Summit on 22/23 June 1980 (see paragraphs 12 and 13 below).

b) The oil producing countries have acquired, since 1973, a very powerful influence over trends in world economic development. The policies they adopt on oil production and pricing and on management of their financial surpluses, will to a large extent determine the economic prospects for developing countries without oil.

c) The Report devotes a special chapter-chapter 8 - to the task of the developing countries. It stresses the need for sensible development policies and for attention to social reforms. The Government welcome this; the responsibility for development in any country must rest with the authorities and people of that country, however much help they seek from outside.
8. As regards international cooperation, the Government participate in a very wide range of discussions in many contexts: the United Nations and its related bodies; the IMF and the World Bank group; the GATT: the Commonwealth; the OECD and International Energy Agency; the European Community; and the periodic economic summits. This has two consequences:

a) The Government are already engaged in international discussion of all problems identified in the Commission's Report, both with their developed partners and with the developing countries. All but a few of the measures proposed in the Report are being considered in one or other of these bodies.

$b$ ) The scope for independent initiatives by the British Government is limited. The requirement is rather for measures which can obtain the collective backing of all the governments concerned. In some areas, notably trade policy, the Member States of the European Community are bound to act jointly, with the Commission as their spokesman. But the Government are active in all these discussions and contribute to working out measures which can reflect the highest degree of mutual interest.

\section{The Emergency Programme}

\section{A. Transfer of Resources}

9. The Report argues [page 254] 'The present predicament of the world economy can be resolved only with a major international effort for the linking of resources to developmental needs, on the one hand, and the full utilisation of under-utilised capacities on the other'. It calls for:

a) Large amounts of additional aid, especially for the poorest countries and regions most seriously threatened by the current economic crisis. The rich countries should commit themselves to a timetable for reaching the target of 0.7 per cent of GNP for their official aid by 1985 .

b) Measures to provide programme lending and assure recycling, to finance the capital needs and debts of middle income countries.

10. The dominant factor affecting the world economy in the early $1980 \mathrm{~s}$ is the rise in average oil prices from $\$ 13$ per barrel in 1978 to over $\$ 30$ per barrel in June 1980. This has had a sharply deflationary effect on world economic activity. The income lost to OECD countries is estimated at $\$ 300-\$ 400$ bn up to 1981 , with a consequent high level of unused capacity. Prices also have accelerated; the OECD average for inflation has risen from 8 per cent in 1978 to 14 per cent now. The Government are very much aware that the non-oil developing countries have suffered most in this context. They face higher prices for their own 
imports; lower demand for their exports because of slack growth in OECD countries; and reduced prospects of help from developed countries because of the latters' own difficulties.

11. The Government are convinced that the OECD countries cannot correct the under-utilisation of capacity by a massive extra injection of spending. A return to the durable and sustained growth needed by all, but especially by the developing countries, will be possible only after their economies have adjusted to the higher price of oil and to the inflationary consequences of this. This adjustment, which will have to be made by developed and developing countries alike, will inevitably produce a period of slower growth.

12. Subject to this major constraint, the Government agree with the Report that priority should be given to:

a) The working of the recycling process. This should ensure inter alia that developing countries which adopt effective adjustment policies should have access to adequate finance to cover the difficulties of transition.

b) Concessional flows of official funds to help those countries, especially the poorest, who do not have ready access to the markets.

13. The deficits of the non-oil developing countries in real terms approach those incurred in 1974-75. But the corresponding OPEC surplus is expected to contract only slowly, so the large deficits may be more protracted. After a net current account deficit of $\$ 40$ bn in 1979 , the non-oil developing countries may face a deficit of around $\$ 55$ bn in 1980 and possibly more in 1981 .

14. The Government believe that, as stated at the Venice Summit, the international capital market can continue to play the primary role in recycling OPEC surpluses to finance these deficits. New net bank lending in 1979 was equivalent to 80 per cent of the deficit of non-oil developing countries. The level of deposits held by the banks is likely to rise, as OPEC surpluses rise. There is likely to be a growing degree of caution among banks about the credit-worthiness of certain countries, as their levels of debt accumulate. The proportion of the total deficit of non-oil developing countries financed by the banks could decline. But bank lending will remain the largest single source of external finance available for them.

15. A larger role is however likely to be required from the international institutions. These can help both by assisting countries to carry out adjustment programmes which will help to ensure continued capital inflows and by providing funds, some on concessional terms, for those in need. The Government believe the International Monetary Fund and the World Bank are capable of playing this role and they welcome increased cooperation between them.

a) The IMF provides financial support to reinforce adjustment policies. Agreement on an economic programme will not only release IMF funds but often enable the country concerned to attract private finance as well. The Government would like to see developing countries coming earlier to the IMF, before their difficulties become acute. They therefore favour an increase in the amounts which countries approaching the IMF may draw. They support the efforts being made by the IMF staff to attract extra funds, eg from OPEC countries, to finance larger drawings. Increased drawings should be linked with programmes designed to promote adjustment in the country concerned. Fund conditionality should be administered flexibly in accordance with the guidelines drawn up in 1979. For countries in very great difficulty, additional backing from governments will be needed to supplement the IMF's efforts, by providing aid as emergency balance of payments support.

b) The World Bank provides longer-term capital principally for development needs. Agreement has been reached over the last year to double the capital of the World Bank, to permit higher levels of lending, and to replenish the funds of the Bank's soft loan affiliate, the International Development Association (IDA). The first priority must be for all to ratify those increases, before seeking further changes in the capital structure. The World Bank is also increasing its non-project lending to promote structural adjustment (often alongside IMF adjustment programmes) and its role in co-financing.

16. Many countries, however, especially the poorest, must remain largely dependent on official aid flows for external finance. Aid-giving has increasingly concentrated on these countries; for instance, aid flows from all sources to the 30 or so 'least developed countries' rose so as to represent 10.3 per cent of their total GNP in 1978, against only 4.1 per cent in 1971.

17. The effort of adjustment to higher oil prices and combating inflation makes it hard for OECD countries to increase their official aid. High inflation in Britain requires the Government to take severe corrective action so that the Aid Programme has had to bear a share in public spending cuts. But the Government stand by the commitment to work towards 0.7 per cent of GNP for its official aid, though without a target date; the percentage in 1979 was 0.52 per cent. The Government welcome the decisions of strongerWestern economies, such as Germany and Japan, to increase their aid both in real terms and as a percentage of GNP. They hope that when the British economy is 
restored to health, British aid will increase again. Meanwhile, the Government will take part in the replenishment of the IDA and are contributing to emergency relief for refugees and the victims of famine.

18. In contrast to the constraints on OECD countries, many OPEC countries have the benefit of large surpluses earned by their higher priced oil. They are already contributing generously to aid the developing countries, especially in the Muslim world. But they have the resources to do more. The Government would strongly favour moves by the surplus OPEC countries to take a greater share in the responsibility for aid and other contributions to non-oil developing countries, as recommended by the Venice Summit.

19. To summarise Government action in this field:

a) The Government are convinced that adjustment to higher oil prices and fighting inflation must be the first priority for all countries. They are taking determined action to restore health to the British economy.

b) They support a major role for the IMF in providing finance for developing countries in deficit, promoting adjustment and helping countries to attract private finance. They have argued for increased access to the IMF by countries in need and for extra sources of finance for larger drawings.

c) They have agreed to the doubling of the World Bank's capital, and support its programme of structural adjustment lending and increased co-financing.

d) They are participating in international support operations for countries in financial difficulty, eg for Turkey, and in joint debt rescheduling, eg for the Sudan. For 17 of the poorest countries, Britain has already converted aid loans to grants or provided equivalent help, worth some $£ 900 \mathrm{mn}$ over the next 20 years.

e) They have taken legislative authority to participate in the latest replenishment of the IDA and hope all the others concerned will do the same.

\section{B. Energy}

20. The Report recommends that there should be an accommodation between oil producing and consuming countries to ensure more secure supplies, more rigorous conservation, more predictable changes of prices and more positive measures to develop alternative sources of energy. The Report advocates an energy strategy which would involve:

a) assured levels of production, with special arrangements for the poorer developing countries; b) targets for consumption of oil and other energy, and conservation standards, for all major consumers; c) prices avoiding sudden major increases but at levels giving incentives for production and conservation;

d) major investment in energy exploration and development in non-oil developing countries; increased research and development on new types of energy, especially renewable forms.

21. The Government are in very large agreement with the Commission's treatment of this subject.

22. The Government consider that all countries, at whatever stage of development, must economise on the use of energy and reduce dependence on oil. The seven Summit countries, including the United Kingdom, bound themselves at Venice on 22/23 June 1980 to take measures to conserve energy in all forms, to develop alternative sources, especially coal and nuclear power, and to reduce the ratio between energy consumption and economic growth. These commitments complement the targets for oil imports in 1980 and 1985 already set in the International Energy Agency and the Community. The Government accept that the long-term trend of oil prices is upward in real terms. They believe that prices and the market mechanism have an essential role to play in ensuring more efficient use of energy.

23. The Government are aware that many developing countries will need outside help to adapt to a world where energy is scarce. They therefore support proposals to assist developing countries to expand and develop their indigenous energy resources. The World Bank is already engaged in a programme of loans for energy development and exploration in non-oil developing countries. These loans should be associated as much as possible with private finance. As was noted by the Venice Economic Summit, the Government would like to see the World Bank examine whether its resources are adequate for this purpose and consider how to improve or expand them. This examination could include the possibility of a new affiliate or facility for energy projects; this idea corresponds to one of the proposals in the Report. The Government are also using their bilateral Aid Programme to promote energy development where this can be done usefully, for example the coal sector in India.

24. But the prospects for the developing countries and for the world economy as a whole will still depend heavily, throughout the $1980 \mathrm{~s}$, on the policies of the OPEC countries. The interests of all will be served if OPEC countries maintain adequate supplies of oil and predictable movements in prices, avoiding sudden shocks to the market. As the examples of 1973-74 and 1979-80 have shown, these can have an extremely damaging effect on economic prospects in both 
developed and developing countries. The Government have always been in favour of discussions with oil producing countries. These could help achieve a stable equilibrium between supply and demand for oil and encourage oil producers to maintain production at adequate levels. Earlier attempts at discussions have not been fruitful. But the Venice Summit has endorsed once again the need for a constructive dialogue between energy producers and consumers.

25. To summarise the Government's action in this field:

a) They are taking measures to save energy at home and develop alternative sources to oil, especially coal and nuclear power. Other Western countries are doing the same.

b) They support measures to enable non-oil developing countries build up their indigenous energy resources. They are helping through bilateral aid programmes and by backing the efforts of the World Bank.

c) They are looking for ways to achieve a dialogue with the oil producing countries, to assure more reliable supplies of oil at more predictable prices.

\section{Food}

26. The Report calls for a programme of increased food production and agricultural development, with additional aid. As a start to a programme for international food security, it advocates early conclusion of an International Grains Agreement and increases in emergency food supplies.

27. The Government consider that the key to the food problem of developing countries is the development, not only of food crops, but of agriculture generally and of the entire rural sector. Farmers must take their own decisions on whether to grow food or cash crops in the light of local conditions. But each government has an important role in setting the framework for these decisions. The crucial areas are: the system of tenure; the share of public investment going to the rural sector; extension advice; storage and the avoidance of losses; and pricing policies which do not penalise farmers in favour of town-dwellers. Individual developing countries which have tackled these related problems have been rewarded with dramatic improvements in agriculture and food production.

28. These are matters for internal policy decisions by the countries concerned. The Government are in favour of external action to reinforce these efforts, as follows:

a) an adequate system of international food security through the creation of coordinated grain stocks; $b$ ) allocation of aid (including food aid) to reinforce agricultural and food development;

c) responding to unforeseen disasters of famine.
29. The Government, along with its European Community partners, remain committed to negotiate a new Wheat Trade Convention which would contain tangible benefits for developing country importers. Work is now in hand in the International Wheat Council on the consideration of new proposals aimed at the objectives of market stability and world food security. The basic mechanism would be a system of nationally held reserve stocks; the accumulation and release of these would be internationally coordinated. Evidence of market instability would trigger consultations to decide what remedial action, if any, was required. The Government want to see special attention given to ways in which the international community might help developing countries to participate fully. These might include help with stock-building and holding obligations; the provision or improvement of storage and other infrastructure; and priority access to stock releases in times of short supply.

30. Both the international financial institutions and individual aid donors have given far greater attention to the needs of the rural and agricultural sector in their programmes in recent years. The Government believe that this must continue. The major role for food aid should be indirect, in meeting import costs that would otherwise have to be paid for and in releasing local funds to reinforce public investment in the agricultural sector.

31. The Government support contributions to the International Emergency Food Reserve by the European Community. These contributions come from the joint food aid programme, to which the Community is committed under the new Food Aid Convention. Relief of other kinds is provided through support for the UN High Commissioner for Refugees, the UN Relief and Works Agency, UNICEF and the World Food Programme, as well as the emergency aid provisions of the Lomé Convention and the Community budget. Bilaterally, the Government respond through their own Disaster Unit and through cooperation with voluntary agencies.

32. To summarise the Government's action in this field:

a) The Government wish to see individual developing countries give increased priority to food and agricultural production in their investments. They will respond, within their ability, to the revised agricultural priorities of aid recipients; they will encourage international bodies to do likewise.

$b$ ) They support the early conclusion of a new Wheat Trade Convention.

c) They are associated with the European Community contribution (increased by over 30 per cent) to the new Food Aid Convention negotiated for the period 
to 30 June 1981. The prime use of food aid should be to intensify development - particularly in agricultureand thus reduce the risk of sudden emergencies. However, the Government agree that the Community should contribute to the International Emergency Food Reserve through its annual allocation under the Food Aid Convention.

\section{Reform of the economic system}

33. The Report calls for:

a) Examination of its proposals for a world development fund, international taxation, use of the IMF's gold and power sharing in international institutions. b) Action by developed countries to liberalise the international trading system, improve access for processed primary products and manufactures from developing countries and restructure their industries to higher productivity.

c) Action by developing countries to expand food production, reduce income inequalities, increase cooperation among themselves and encourage a positive investment climate.

34. The Government's preference is for adapting the present world economic system and making the best use of existing organisations.

35, The IMF and the World Bank have already started to examine the suggestions made in the Report. Proposals intended to benefit developing countries will be major items on the agenda for IMF and World Bank meetings in September/October 1980. The Government see merit in the existing structure of these bodies, which reflects the financial stake of the members in them. They also welcome the process of adaptation, including the recognition given to Saudi Arabia as the second largest creditor to the IMF and the welcome extended to the Chinese Government by the IMF and World Bank this year. They prefer to expand the operations of these bodies to the creation of a new institution. They doubt whether international taxation for aid purposes would be either equitable or possible to implement, or would lead to a net increase in aid flows.

36. The liberalisation of the world trading system has been considerably extended by the GATT
Multilateral Trade Negotiations, concluded in 1979, with many provisions of benefit to developing countries. The Government would welcome wider adherence by developing countries to these agreements. The Government will be active in the review and improvement of the Community's Generalised Preference Scheme from 1981 onwards, which provides preferential access to Community markets for manufactures and for certain processed primary products from developing countries. Many developing countries already enjoy completely free or preferential access to the Community's market through the provisions of the second Lomé Convention, concluded in 1979 and due to enter into force this year. In the commodities field, the Government have been active in the negotiations for a Common Fund, which were successfully concluded on 28 June 1980 .

37. The Government welcome any progress which developing countries can make in the reforms proposed for them in the Commission's Report.

38. To summarise Government action in this field:

a) The Government support the adaptation of the IMF and World Bank to changing needs, while preserving their basic structure.

$b$ ) As a member of the European Community, they are promoting the steady liberalisation of world trade, through the full implementation of the recent GATT agreements, the conclusion of the Lomé Convention and the renewal of the Community's generalised preferences.

c) They welcome the creation of a Common Fund for commodities.

\section{Conclusion}

39. This Memorandum has largely concentrated on issues where the Government have already taken a position and are participating in international action. Other proposals contained in the Report, including a number examined in the annex', will require further national and international consideration before decisions on them can be reached. Many may be followed up in the International Development Strategy which should be adopted shortly by the United Nations, or in the 'Global Negotiations', now in preparation and likely to take place at the UN in 1981.

\footnotetext{
' not reproduced here
} 